\title{
ANALYSIS ACCEPTANCE OF PLATFORM TECHNOLOGY DIDIMAX BERJANGKA IN PEKANBARU USING THE UTAUT METHOD
}

\author{
Rizki Novendra \\ Department of Information System, Faculty of Computer Science, Universitas Lancang \\ Kuning \\ rizkinovendra@unilak.ac.id
}

Received : 21 October 2020, Resubmit: 11 November 2020 Revised: 03 Desember 2020 , Accepted : 05

Desember 2020

\begin{abstract}
This study discusses the acceptance of PT Didimax's metatrader technology. To carry out the analysis in this study using the UTAUT method. The UTAUT method has four independent variables and two dependent variables. It is through these variables that the level of technology acceptance is explained. The results of this study from 121 respondents showed that the Performance Expectancy variable had a positive and significant impact on behaviour intention, the condition t counted 3.184>t table 2015 Sig $0.002<0.05$ and facilitating condition $t$ count 4.224> t table 2015 Sig $0.000<0.05$. also has a positive and significant impact on use behaviour.
\end{abstract}

Keywords : Analysis, Technology Acceptance, Metatrader Platform, UTAUT

\section{Introduction}

The development of the internet which is currently developing rapidly has opened many new technologies in the world including digital currency called Forex Trading. Forex Trading is the activity of trading foreign currencies with the sole purpose of making a profit. The trading platform (trader) makes transactions using metatrader4 software provided by PT. Didimax Berjangka as a broker. Metatrader4 is an application provided by brokers to connect customers (traders) with foreign exchange.

PT. Didimax Futures is a futures brokerage company that specializes in Currency (Forex) trading, with very competitive spreads and fees. PT. Didimax Berjangka operates under a license and is under the supervision of BAPPEBTI. BAPPEBTI is the Commodity Futures Trading Supervisory Agency, which is tasked with supervising and regulating Indonesian futures trading activities. Therefore, every broker that provides official trading activity services in Indonesia must go through regulations from Bappebti.

This research will discuss about technology acceptance, namely the acceptance of platform technology at PT. Didimax Futures. The didimax platform acceptance evaluation will use the UTAUT method which is widely used in studies regarding the acceptance of new technology. This study uses the UTAUT method, which is a model that explains user behaviour towards information technology. The UTAUT model shows that the intention to behave (behavioural intention), behaviour to use a technology (use behaviour), is influenced by performance expectations, effort expectancy, social influence, and facilitating conditions. The fourth Factors are moderated by the factors of gender and age.

Problems that often occur in the community regarding the trading platform application at PT. Didimax Berjangka Pekanbaru is a lack of public trust in using the trading platform application, due to the lack of public understanding of knowledge of platform technology in the form of applications and frequent fraud problems, where many companies act on behalf of investments to benefit society but the community does not get benefits and certainty from these investments.

\section{Literature Review}

Research conducted by (Gunawan \& Novendra, 2017) on the acceptance of bitcoin technology in Indonesia. This study uses the UTAUT method with several variables: PE, EE, SI, FC, BI and UB. Gender and age factors were assumed to moderate the relationship between 
the four factors and behavioural use and intention. Empirical data for these factors were collected using a questionnaire from 49 respondents. The statistical significance of the relationships was evaluated by multivariate regression analysis. The result is a model that fits the data with $\mathrm{R} 2=0.678$. This indicates a high level of fitness. The analysis shows that the factors of performance expectations and social influence factors greatly influence the behavioural intention to use Bitcoin with a t-statistic value of 3.835 (p-value $=0.000$ ) for the previous factor and $1.948(0.059)$ for the last factor.

Research conducted by (Mahendra, 2016) aims to find out the perception of the UTAUT variable on the company's ERP system. In this study, 44 respondents were determined by purposive sampling technique. The results showed that perceptions of performance expectations, business expectations, social influences, and conditions that facilitate simultaneous influence on the interest to behave using the ERP system at PT GBS. Previous research was conducted by (Mursityo et al., 2019). This study evaluates the acceptance level of SIAKD Desktop technology using the UTAUT method. The results of the analysis show that only the condition of the facility has a significant positive effect on the behaviour of using the SIAKAD Desktop. The UTAUT model can only explain $44.8 \%$ of the variants of the SIAKAD Desktop usage factor which are included in the moderate category. Therefore it is necessary to develop a research model constructor so that the prediction of variance accuracy from the research model increases. In addition, it is hoped that further research can cover a wider target population so that the data is more reliable

The research was conducted by (Sriyeni et al., 2018) in this study to find out whether the Computer Based Test (CBT) technology was fully accepted and useful in teaching and learning activities. This research uses the UTAUT method with several variables. The results of this study state that the variable performance expectancy, business expectation, social influence, facilitating conditions, attitudes towards the use of technology have a significant effect on the behavioural interest variable, and the behavioural interest variable has a significant effect on the usage behaviour variable. Social influence variables have the greatest influence on acceptance and use of computer based tests (CBT) as a medium for online examinations due to government policies in implementing national exams Research conducted by (Mustaqim et al., 2018), in this study conducted an analysis of the level of technology acceptance of E-commerce XYZ using the UTAUT method. The results found from this study are only social influence factors that affect a person's intention to use e-commerce XYZ, while the performance expectancy and effort expectancy factors do not have a significant effect on behavioural intention.

Research was conducted by (Wolfe et al., 2017), the purpose of this study to find out and analyze online registration system at RSUD dr.M. Soewandhie by using UTAUT method. The result showed that individual characteristic which has $\mathrm{p}$ value below 0,05 was experience, knowledge and IT skills. Performance expectancy $(\mathrm{p}=0,044)$ significantly influence behavioural intention, whereas effort expectancy $(p=0,982)$ and social influence $(p=0,124)$ do not. Facilitating condition $(p=0,812)$ and behavioural intention $(p=0,189)$ had no influence with use behaviour because $\mathrm{p}$ value was above 0,05 . In conclusion, performance expectancy has a significant influence with behavioural intention, therefore experience, knowledge and IT skills had influence with use behaviour online registration in RSUD dr.M. Soewandhie Surabaya.

Research conducted by (Amalia \& Brata, 2018), the purpose of this study is to find out the acceptance and use of blog technology for teachers. The method used in this research is UTAUT. The results obtained in the form of free blogs that are most widely used by SMK teachers as alternative learning media are (1) blogspot at 63\%, wordpress by $18.5 \%$, Edmodo by $17.4 \%$ and others by $1.1 \%$; (2) the results of the implementation of the questionnaire using the UTAUT method resulted in an effort expectancy of $94.02 \%, 89.50 \%$ of performance expectancy, $88.04 \%$ of social influence, $86.04 \%$ of supporting facilities, $85.71 \%$ of use behaviour and $84.39 \%$ of behavioural intention.

The research was conducted by (Farabi, 2016) with the aim of finding out the level of acceptance of the information system of zakat infaq sodaqoh and waqf using the UTAUT method. The results obtained are that the acceptance and use of SIZISW is influenced by the variable Performance Expectancy, Social Influence and Facilitating Condition. Meanwhile, Effort Expectancy has no effect, while moderating variable has an effect in this study. The 
research was conducted by (Soebali \& Mahendra, 2017) with the aim of finding out the level of acceptance of Gojek Application using UTAUT method. The result is known that the simultaneous factor performance expectancy, effort expectancy, social influence, and facilitating conditions and significant positive effect on use behaviour Gojek Application. While partially, it is known that performance expectancy and social influence which has positive and significant effect on use behaviour Gojek Application. While effort expectancy and facilitating conditions not have a positive and significant effect on use behaviour Gojek Application

The research was conducted by (Puspitasari et al., 2013), in this study to find out about the acceptance of the Hospital Management Information System (SIMRS) using the UTAUT method. The results of this study are the five variables that affect the level of user acceptance, namely the suitability of tasks and technology (KTT), expected performance (KDH), social influence (PS), the expected level of convenience (TKD), and the condition of existing facilities (KF). affect the level of user acceptance by $70.75 \%$.

\section{Research Methods}

This section contains a complete and detailed description of the steps undertaken in conducting of research. In addition, the research step also needs to be shown in the form of flowchart of research or framework step in complete and detailed including reflected algorithm, rule, modeling, design and others related to system design aspect.

The stages of the flow in this study are :

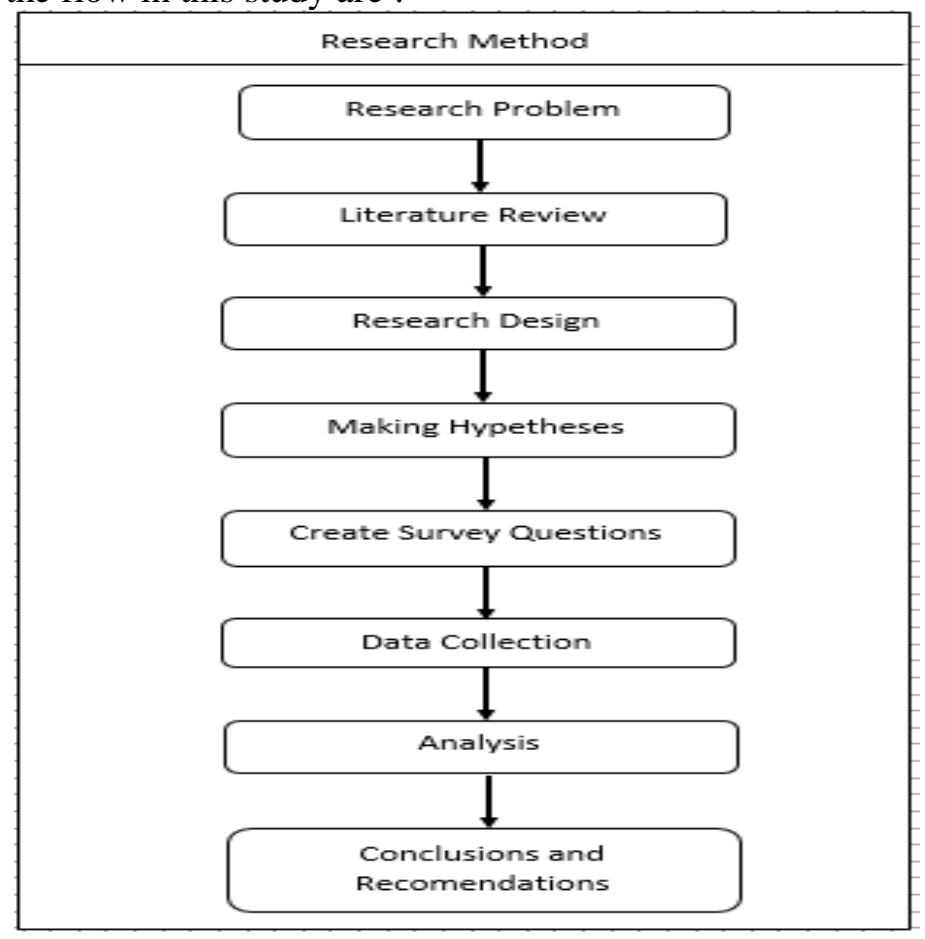

Fig. 1. Research Method

\section{Research Problem}

The formulation of the problem in a research proposal is the most basic thing. The formulation of the problem will determine what discussion will be carried out in the research. The questions raised in the formulation of the problem will then be answered in the research process and will be systematically stated in the research report. All discussion in the research report, including all discussions regarding the theoretical framework and methodology used, all refer to the formulation of the problem. Therefore, it becomes a central point.

\section{Literature Review}

An activity that includes finding, reading and reviewing research reports and library materials relevant to the research that will be carried out by the research plan.

\section{Research Design}


The research design is a research design that is used as a guide in conducting the research process. The research design is a plan on how to collect and analyze data so that it can be carried out economically and in harmony with the research objectives. The research design aims to provide a clear and structured handle to the researcher in conducting his research.

\section{Making Hypotheses}

Hypothesis is a statement regarding the state of the population or parameters to be verified based on the data obtained from the research sample. The procedures for understanding acceptance rates are defined in detail including data collection and analysis methods. In the block hypothesis, the research problem is stated into twelve hypotheses. It will be evaluated by collecting empirical data and statistical analysis. In addition, questionnaires were created and distributed to obtain data on constructs: such as performance expectations, business expectations, social influences, facilitation conditions, behavioural intentions, and usage behaviour. Then, data from the four moderate variables of gender, age, experience, and user were also collected. In the analysis and conclusion block, a statistical analysis will be carried out from which conclusions about the twelve hypotheses will be drawn.

UTAUT framework reproduced from Venkatesh et al. (2003) on the structure of the hypothesis in the UTAUT framework. This structure is broken down into twelve hypotheses. The 12 hypotheses are as follows:

H1 = Performance expectations have a positive effect on behaviour.

$\mathrm{H} 2=$ Performance expectations and relationship behaviour intention are moderated by gender.

H3 = Performance expectations and relationship behaviour intentions moderated by age.

$\mathrm{H} 4=$ Business expectations have a positive effect on intention behaviour.

H5 = Effort expectation and moderated behaviour intention relationship based on gender.

H6 = Effort expectation and behaviour intention relationship moderated by age.

$\mathrm{H} 7$ = Social influence has a positive effect on intention behaviour.

$\mathrm{H} 8=$ Social influence and behaviour intention relationship is moderated based on gender.

$\mathrm{H} 9$ = Social influence and behaviour intention relationship is moderated by age.

$\mathrm{H} 10=$ The facilitation condition has a positive effect on the use of behaviour behaviour.

H11 = Facilitating conditions and using behaviour relationships moderated by age.

H12 = Behavioral intention has a positive effect on the use of behaviour

\section{Create Survey Questions}

In creating a survey, how you get your information and what type of questions you have plays an important role in making a successful survey. Survey questions have 4 types of questions as follows:

a. Multiple Choice Questions

This type of question allows survey respondents to select one or more options from a list of answers that the researcher determines. The researcher should use multiple choice questions when the researcher has a fixed number of choices.

b. Rating Scale Question

With rating scale questions, survey respondents choose a single rating for the researcher question. Customer satisfaction survey questions often use a Likert scale to measure customer opinions or attitudes.

c. Question Comment Or Essay

Open survey questions do not provide specific answer options, and require respondents to type their answers in the comments box. The feedback can then be viewed individually or with advanced text analysis tools, such as Survey Monkey's Open Ended Question Analysis tool.

d. Demographic Questions

If, for example, the researcher needs information about the background or income level Data Collection of the respondent, demographic survey questions will serve the researcher well.

Data collection aims to obtain information or data needed by researchers. Data collection was carried out by conducting observations, interviews and questionnaires.

Analysis 
Analysis is the ability to solve or decompose a material into smaller components so that it is easy to understand.

\section{Conclusions and Recommendations}

At this conclusion stage contains the points of all the stages that have been carried out. And suggestions are solutions that are intended to solve constructive and critical problems for this research.

\section{Results and Discussions}

Results and Discussion is a section that contains all scientific findings obtained as research data. This section is expected to provide a scientific explanation that can logically explain the reason for obtaining those results that are clearly described, complete, detailed, integrated, systematic, and continuous. The discussion of the research results obtained can be presented in the form of theoretical description, both qualitatively and quantitatively. In practice, this section can be used to compare the results of the research obtained in the current research on the results of the research reported by previous researchers referred to in this study. Scientifically, the results of research obtained in the study may be new findings or improvements, affirmations, or rejection of a scientific phenomenon from previous researchers.

This research was conducted to determine the level of public acceptance of the existing platform system at PT. Didimax Futures. In this study, researchers chose to use the Unified Theory of Acceptance and Use Of Technology (UTAUT) method. In this method, the researcher uses four variables, including performance expectations, business expectations, social influences, and facility conditions, moderated by gender and age factors. This research was started from March 1, 2020 to completion. The target of this research is active users at PT. Didimax Berjangka Pekanbaru who has used or has a trading account. The population in this study amounted to 175 and the number of samples obtained using the Slovin formula was 121 users. The data for this study were obtained from PT. Didimax Berjangka Pekanbaru, as well as distributing questionnaires containing statements regarding the acceptance of Didimax Berjangka platform technology which will be filled in by users (customers) according to a predetermined number of samples. The data obtained will be processed by researchers with the help of the IBM SPSS version 16 application.

Using regression analysis will help find the relationship of two or more variables or the dependence of a variable with other variables. UTAUT has four independent variables, namely performance expectancy, effort expectancy, social influence, facilitating conditions and two dependent variables, namely the intention to use technology (behavior intention), the behavior of using technology ( use behavior) and two moderating variables, namely gender and age. To determine the effect of the independent variable, the dependent variable and the moderating variable gender and age, a regression analysis was performed. The following is Figure 2 of the independent, dependent and moderating variables UTAUT which is the reference for regression analysis: 


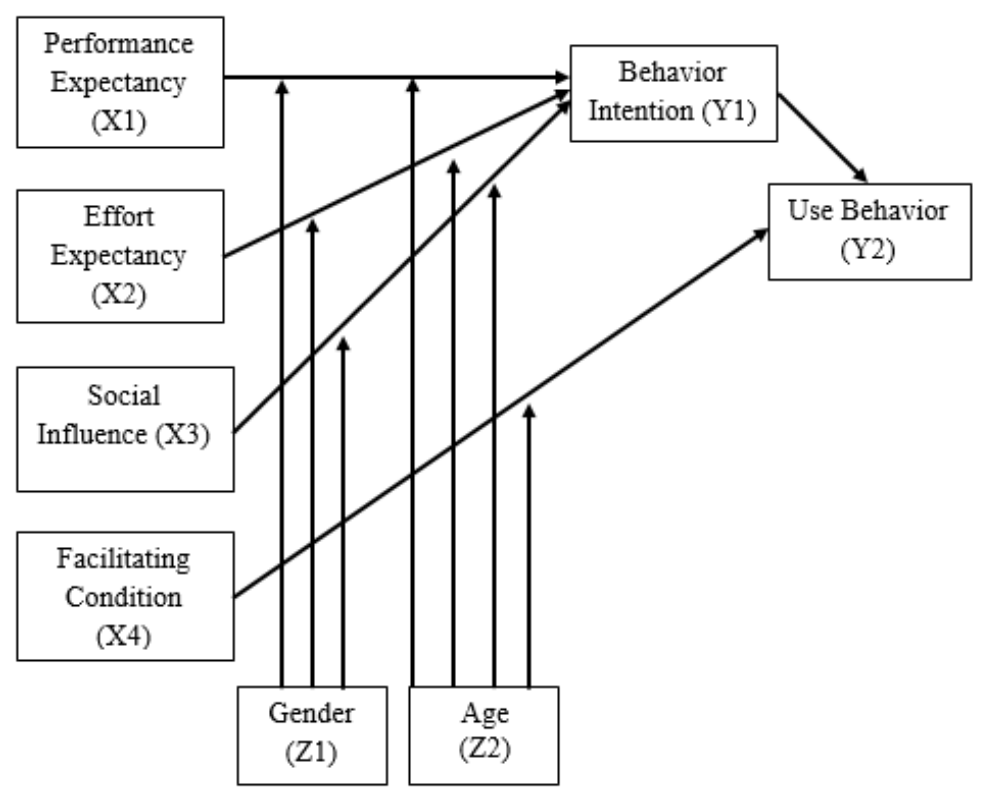

Fig. 2. Independent, Dependent, and Moderating Variables

Analysis or regression test using SPSS IBM Statistics 16 software. While the data used comes from the research questionnaire. The following table 1 summarizes the results of the regression test with the dependent variable Behavior Intention:

Table 1 - Regression Y1

\begin{tabular}{lccc}
\hline $\begin{array}{c}\text { Variable } \\
\text { Constant }\end{array}$ & $\begin{array}{c}\text { Regression } \\
\text { Coefficient }\end{array}$ & t Count & Significant \\
\hline X1 & 0.147 & 3.184 & 0.002 \\
X2 & 0.175 & 4.305 & 0.000 \\
X3 & 0.100 & 1.642 & 0.103 \\
Z1 & 0.165 & 0.554 & 0.584 \\
Z2 & 0.358 & 1.180 & 0.240 \\
X1.Z1 & 0.066 & 0.847 & 0.399 \\
X2.Z1 & 0.145 & 1.564 & 0.120 \\
X3.Z1 & 0.090 & 1.006 & 0.316 \\
X1.Z2 & 0.105 & 1.356 & 0.178 \\
X2.Z2 & 0.145 & 1.518 & 0.132 \\
X3.Z2 & 0.102 & 1.139 & 0.257 \\
\hline
\end{tabular}
Behavior :

Following are the results of the regression test with the dependent variable Use Table 2 - Regression Y2

\begin{tabular}{lccc}
\hline \multicolumn{1}{c}{$\begin{array}{r}\text { Variable } \\
\text { Constant }\end{array}$} & $\begin{array}{c}\text { Regression } \\
\text { Coefficient }\end{array}$ & t Count & Significant \\
\hline $\mathrm{X} 4$ & 0.289 & 4.224 & 0.000 \\
$\mathrm{X} 4 . \mathrm{Z2}$ & 0.110 & 1.448 & 0.150 \\
$\mathrm{Y} 1 . \mathrm{Y} 2$ & 0.328 & 24.957 & 0.000 \\
\hline
\end{tabular}

\section{Conclusion}


Based on the results of the study, entitled analysis of technology acceptance of platform technology at PT. Didimax Berjangka in Pekanbaru, this study gets the conclusions obtained from the results and discussion including:

1. From the results of research on platform technology from a total of 121 users (customers) who have used or have a trading account at PT. Didimax Futures Pekanbaru. Of the 121 respondents, 71 of them showed the results agreed according to table 5.4, it can be concluded that the acceptance of platform technology at PT. Didimax Berjangka agreed.

2. The level of acceptance of platform technology has a significant correlation, seen from the $\mathrm{H} 1$ hypothesis test, which states that the variable performance expectancy has a positive and significant impact on behavior intention and H10 facilitating conditions have a positive effect on use behavior, the two hypotheses prove that the PE and FC variables are factors that influence users. in using platform technology.

3. EE variable does not have a positive and significant effect on behavior intention and on the contrary, social influence on behavior intention has a positive but insignificant effect

\section{References}

Amalia, F., \& Brata, A. H. (2018). Analisis Tingkat Penerimaan Sistem E-Learning menggunakan Blog Gratis sebagai Alternatif Media Pembelajaran pada Guru. Jurnal Teknologi Informasi Dan Ilmu Komputer, 5(3), 335. https://doi.org/10.25126/jtiik.201853640

Farabi, N. A. (2016). Analisis Penerapan Sistem informasi ZISW Dengan Menggunakan Metode UTAUT. Indonesian Journal on Computer and Information Technology, $1(2), 71-79$.

Gunawan, F. E., \& Novendra, R. (2017). An Analysis of Bitcoin Acceptance in Indonesia. ComTech: Computer, Mathematics and Engineering Applications, 8(4), 241. https://doi.org/10.21512/comtech.v8i4.3885

Mahendra, I. (2016). Analisa Penerimaan Sistem Enterprize Resurce Planing (ERP) Pada PT GBS Megguakan Unified Theory Of Acceptace And Use Of Techologi (UTAUT). Jurnal Pilar Nusa Mandiri, XII(2), 190-200.

Mursityo, Y. T., Saputra, M. C., \& Herlambang, A. D. (2019). Analisis Penerimaan Pengguna Aplikasi Siakad Desktop Universitas Brawijaya Menggunakan Utaut. Joutica, 4(1), 168. https://doi.org/10.30736/jti.v4i1.280

Mustaqim, R., Kusyanti, A., \& Aryadita, H. (2018). Analisis Faktor-Faktor yang Memengaruhi Niat Penggunaan E-Commerce XYZ Menggunakan Model UTAUT (Unified Theory Acceptance and Use Of Technology). Jurnal Pengembangan Teknologi Informasi Dan Ilmu Komputer, 2(7), 2584-2593. http://jptiik.ub.ac.id/index.php/j-ptiik/article/view/1653/608

Puspitasari, N., Permanasari, A. E., \& Nugroho, H. A. (2013). Analisis Penerapan Sistem Informasi Manajemen Rumah Sakit Menggunakan Metode UTAUT dan TTF. Jnteti, 2(4), 225-232. http://jnteti.te.ugm.ac.id/Journal/November 2013/225232 JNTETI_13-11-12L Novianti.pdf

Soebali, L. F., \& Mahendra, I. (2017). Analisa Faktor-Faktor Yang Mempengaruhi Penerimaan Dan Penggunaan Aplikasi Go-Jek Menggunakan Unified Theory of Acceptance and Use of Technology (UTAUT). Jurnal Pilar Nusa Mandiri, 13(1), $136-144$.

Sriyeni, Y., Antoni, D., \& Akbar, M. (2018). ... dan Penggunaan Teknologi Computer 
Based Test (CBT) sebagai Media Ujian Online dengan Model Uified Theory of Acceptance And Use of Technology (UTAUT). Jurnal Teknologi Dan ..., 08(01), 93-104. http://eprints.binadarma.ac.id/4291/

Wolfe, D. T., Hermanson, D. R., Ii, B. A. B., Diri, A. K., Diri, P. K., Chotimah, C., Rohayati, S., Мурашко M.A., كايّلان, سادوك, غلامحسين, ث., Akademik, K., Reza Yuka Satria Pratama, 加藤真也, 小林千秋中西優子, Rusno, Ips, B., Kelas, S., Sdn, I. V, Tahun, T., ... Noviyani, D. I. (2017). No Titleخلاصه روانيزشكى. Educational Psychology Journal, 2(2), 65-72. 